\title{
Assessment of Heavy Metals Level in Water and Sediments from Lake Njoboliyo, Yola-South, Adamawa State, Nigeria
}

\author{
Kefas, M. Michael, K. G. Kaitanga, G. S Jidauna, S. B.
}

Department of Fisheries, Modibbo Adama University of Technology,Yola, P.M.B 2076,Adamawa State, Nigeria

\begin{abstract}
Assessment of Heavy metals levels in Water and Sediment from Lake Njoboliyo, Yola-south, Adamawa State, Nigeria was conducted for the period of five months (January-May, 2018). Data were collected in three different sites bi-weekly in triplicate. The concentrations of heavy metals in water ranges during the period of the research were Cadmium $(0.0144 \mathrm{mg} / \mathrm{l}$ to $0.0256 \mathrm{mg} / \mathrm{l})$, chromium $(0.0133 \mathrm{mg} / \mathrm{l}$ to $0.0222 \mathrm{mg} / \mathrm{l})$, Copper $(0.0133 \mathrm{mg} / \mathrm{l}$ to $0.0244 \mathrm{mg} / \mathrm{l})$, Iron $(1.3411 \mathrm{mg} / 1$ to $4.2600 \mathrm{mg} / \mathrm{l})$, Zinc $(0.0114 \mathrm{mg} / \mathrm{l}$ to $0.4956 \mathrm{mg} / \mathrm{l})$. There was significant difference $(\mathrm{P}<0.05)$ for all the heavy metals between sites and Months. All the heavy metals observed in the water samples were higher than the WHO except Copper which was within WHO permissible limits, indicating that the pollution of Lake Njoboliyo is moderate. The concentration of heavy metals in sediment ranges during period of study were Cadmium ranged between $0.0267 \mathrm{mg} / \mathrm{kg}$ and $0.0700 \mathrm{mg} / \mathrm{kg}$, Chromium ranged between $0.0144 \mathrm{mg} / \mathrm{kg}$ and $0.0467 \mathrm{mg} / \mathrm{kg}$, Copper ranged between $0.0166 \mathrm{mg} / \mathrm{kg}$ and $0.3533 \mathrm{mg} / \mathrm{kg}$, Iron ranged between $26.1167 \mathrm{mg} / \mathrm{kg}$ and $28.8644 \mathrm{mg} / \mathrm{kg}$, Zinc ranged between $0.1333 \mathrm{mg} / \mathrm{kg}$ and $0.3878 \mathrm{mg} / \mathrm{kg}$, There was significant difference $(\mathrm{P}<0.05)$ for all the heavy metals between sites and Months. All the heavy metals recorded in the sediment were within the permissible limit recommended by WHO and FEPA except Cadmium, indicating that the pollution of Lake Njoboliyo is moderate.
\end{abstract}

Keywords: heavy metals, sediment, water, Lake Njoboliyo

DOI: $10.7176 / \mathrm{JNSR} / 9-14-03$

Publication date:July $31^{\text {st }} 2019$

\section{INTRODUCTION}

Water is one of the important constituents of life support. It is indeed a wonderful chemical medium which has unique properties of dissolving and carrying in suspension a huge variety of chemicals, thus it can get contaminated easily (Santra, 2005). Natural surface water bodies often have impurities from various sources. The impurities may be suspended particles, colloidal materials and may also be dissolved cationic and anionic substances. Various kinds of natural and man-made activities-industrial, domestic, agricultural and others are day by day creating water pollution problem particularly in fresh water system. Water quality is fundamental to the health and sustenance of aquatic ecosystems and hydrology. The benefits of renewable freshwater to humans include water for drinking, irrigation, industrial uses, production of fish, and for such in-stream uses as recreation, transportation and waste disposal (Jackson et al., 2001).

Water pollution has become a global problem. Water is essential to all living organism and in all aspect of human life. Unfortunately, the availability and quality of water have been impacted upon by both natural and anthropogenic sources leading to poor water quality and productivity of aquatic (FAO, 1992). The sources of water pollution vary and involve almost every significant human activity (FEPA 2003). The ever increasing impact of human activities upon our aquatic resources has spurred a sense of stewardship as never before. Diverse use and increased demand for water has put enormous stress on our water supply, its quality and the aquatic life and habitat it sustain (Santra, 2005). The intended use determines the level of water quality that must be maintained. These include mostly the dumping of domestic wastes, sewage, agricultural wastes and industrial effluents into water bodies (Collocott and Dabson, 1974). The wastes dumped on land are also eventually washed into water example animal dung, litters, wind deposited pollutants. Also disturbances of the soil mantle by ploughing during cultivation, road making, stream irrigation/channelization, and mining break the protective vegetation cover and encourage soil washout by storm water during rainfall. In some areas, air pollutants like oxides of nitrogen and sulphur become acidic contaminants during rainfall (Ademoroti, 1996a). Increase in industrialization as a result of modern and sophisticated technology has introduced many synthetic materials into water environment. Some may be toxic or carcinogenic. The wastes arising from them find their way into water bodies, and hence they become contaminated. Fertilizers and other nutrients used to promote plant growth on farms and in gardens may find their way into water (Santra, 2005).

Sediment quality is a good indicator of pollution in water column where it tends to concentrate the heavy metals and other organic pollutants. These sediments are deposited on the bottom and constitute with autochthonous deposited the total sediments of the lakes and rivers serving as a sink or depository reservoirs for heavy metals. Sediment and soil particles carried to a streambed, lake, or ocean, can also be a pollutant if it is present in large amounts. Soil erosion produced by the removal of soil-trapping trees near waterways, or carried by rainwater and floodwater from croplands, strip mines, and roads, can damage a stream or lake by introducing 
too much nutrient matter. This leads to eutrophication. Sediment can also cover streambed gravel in which many fishes lay their eggs (Wetzel, 1979). Analysis of sediments offers several advantages, particularly in terms of providing time average values for pollutant abundance. However, it is difficult to account for the effects of particle size and organic carbon content on metal levels. In addition, no simple methods exist to determine the bioavailability of metals in sediments on the basis of these problems, the use of organism is most widely employed as a method to monitor heavy metals in the aquatic environment (Philips, 1990).

\section{MATERIALS AND METHODS \\ STUDY AREA}

Njoboliyo Lake lies within the latitude $9^{0} 12^{\prime} \mathrm{N}$ to $16^{0} 15^{\prime} \mathrm{N}$ and longitude $12^{0} 28^{\prime} \mathrm{N}$ to $12^{0} 43^{\prime} \mathrm{E}$. The Lake is found in eastern part of Yola-South Local Government Area of Adamawa State (Fig. 1). The major ethnic groups of this area are Bwatiye, Fulbe, Mbula and few migrant fishers that comprise the Hausa, Jukun and Agatu. Some of these migrant fishers have over the years become indigenes to that area ( Ladu and Neiland, 1997). The Lake is wet flooded plain lake found adjacent to River Benue, this Lake has its course from River Nafari and Chigari as inlet and empties into River Benue. The Lake is perennial, Chigari and Nafari take their course from the Mandara highland on entering Nigeria. They meander along their ways with continues deposition of alluvia's and sands, leading to formation of many oxbow lakes within the geographical location of the Benue (Adebayo and Tukur 1999). River Njoboliyo is one of the main sources of water in that area where fishing, farming irrigation, domestic uses etc are being done. The main sources of water apart from rainfall are surface and ground water. The river is well dissected by network of rivers. The study was conducted at the Lake Njoboliyo and the study sites were include (Site A), (Site B) and (Site C) water samples and sediments and was collected from the above mentioned location.

\section{Duration of Sampling}

The study was conducted for the period of five months (i.e from January-May, 2018). Water and sediment samples were collected bi-weekly in triplicate for five months.

\section{Sediments Sampling}

Sediments were sampled from surface using a homemade Auger sampling device as described by Ladigbolu, (2010). The samples were packed in plastic bags that have been previously soaked in $10 \% \mathrm{HNO}_{3}$ (Nitric acid) and 1:1 HCL (hydrochloric acid) for $24 \mathrm{hrs}$ followed by rinsing with distilled water and then allowed to drain to dryness. Composite of one kilogram of sediments was collected at each sampling sites. Sediments were preserved for the analysis of heavy metals.

\section{Determination of Heavy Metals in water}

Water samples collected for heavy metals analysis were acidified immediately after collection by adding $3-4 \mathrm{~m}^{3}$ of concentrated $\mathrm{HNO}_{3}$ per litre of sample, and then preserved the samples by minimising absorption of the trace metals on to the walls of the container (Bartly and Gardner, 1977). Heavy metals ( $\mathrm{Pb}, \mathrm{Cu}, \mathrm{Cd}, \mathrm{Zn}, \mathrm{Cr}$. Fe) were determined as described by Ajayi and Osibanjo (1981) using a Buck Scientific 200A model, Atomic Absorption Spectrophotometer (AAS) (APHA 1995, APHA 2005).

\section{Determination of Heavy Metals in Sediments}

All batches of Sediment samples were air dried in the laboratory before homogenizing. The sample was ovendried to constant weight at $105^{\circ} \mathrm{C}$. The samples were then grounded using mortar and pestle and sieved through $2 \mathrm{~mm}$ mesh size to remove coarse materials. $5 \mathrm{~g}$ of each of the $2 \mathrm{~mm}$ mesh sized sieved sediments were digested separately using the method described by Lee and Cundy (2001) and the metals $\mathrm{Pb}, \mathrm{Cu}, \mathrm{Cd}, \mathrm{Zn}, \mathrm{Cr}$ and Fe were analysed using Buck scientific 200A model (AA-ES) atomic spectrophotometer(AAS) .

\section{Statistical Analysis}

Data obtained in this study were analysed using one way analysis of variance (ANOVA) of the SPSS Version 15.5 software to determine the mean significant difference in heavy metals in the sampling stations (Steel and Torrie, 1990). 


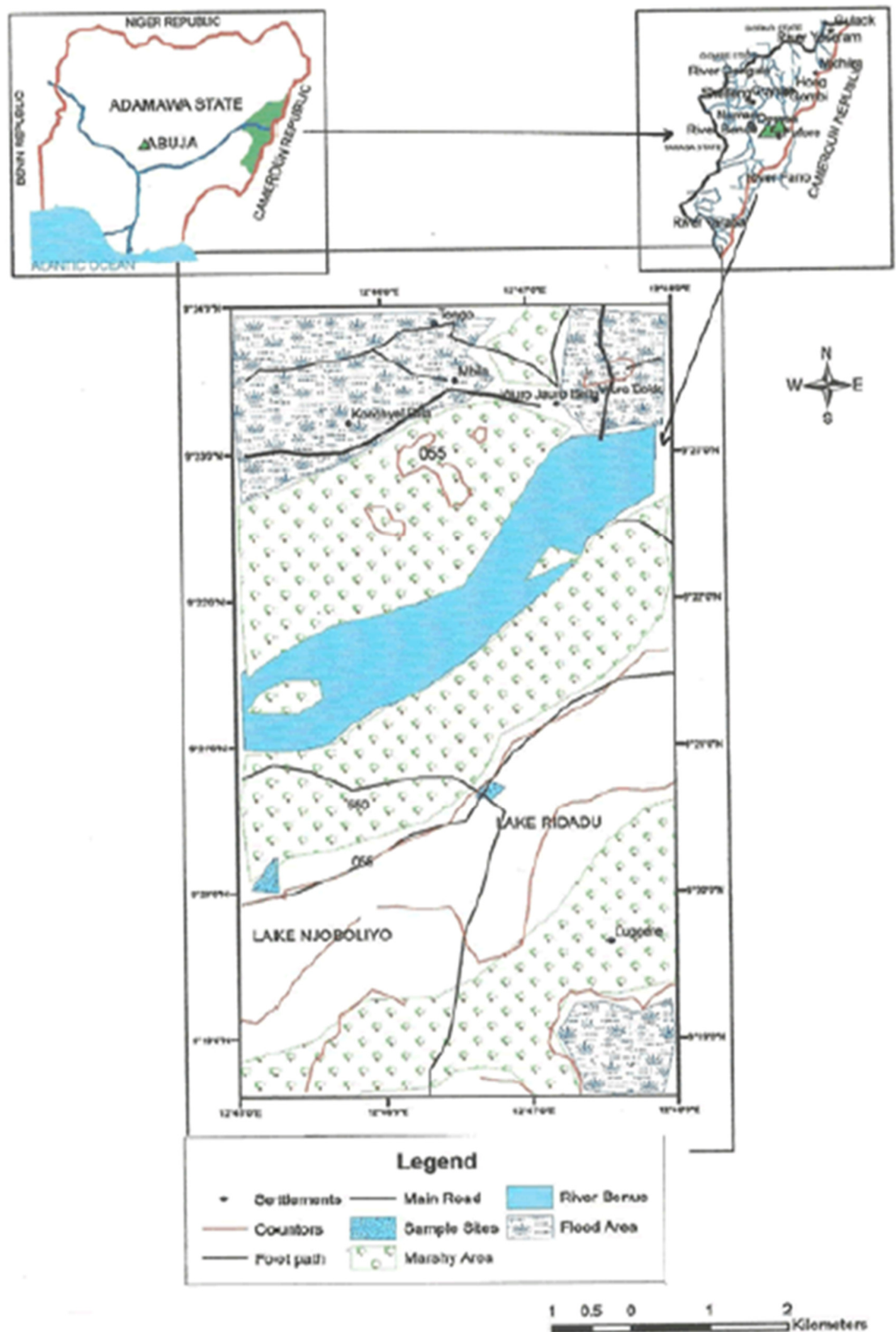

Fig 1: Map of Study Area (Lake Njoboliyo)

\section{RESULTS}

Heavy metal concentration in water

The monthly mean concentration of $\mathrm{Cd}, \mathrm{Cr}, \mathrm{Cu}, \mathrm{Fe}$ and $\mathrm{Zn}$ in water of Lake Njoboliyo are shown in table 1, 2 and 
3. The lowest concentration of Cd $(0.0144 \mathrm{mg} / \mathrm{l})$ was recorded at sites A, B and C from the months of January to May respectively in all the sites while the highest concentration $(0.0256 \mathrm{mg} / \mathrm{l})$ was recorded at site A in the month of May. There was significant differences $(\mathrm{p}<0.05)$ in the months of February to May at all the sites compared to the month of January. The highest concentration of $\mathrm{Cr}(0.0222 \mathrm{mg} / \mathrm{l})$ was recorded at sites B and C in the months of January, April and May while the lowest concentration of $\mathrm{Cr}$ was recorded....... There was significant differences $(p<0.05)$ in the months of April and May at all sites compared to the months of January-March. The highest concentration of $\mathrm{Cu}(0.0244 \mathrm{mg} / \mathrm{l})$ was recorded at site $\mathrm{B}$ in the months of February and April while the lowest $(0.0133 \mathrm{mg} / \mathrm{l})$ was recorded at site $\mathrm{A}$ in the month of May. The results showed that there was significant differences $(p<0.05)$ in the months of February and April at all sites compared to the other months (January, March and May). The monthly mean concentration of $\mathrm{Fe}$ in the water samples ranged from $(4.2600 \mathrm{mg} / \mathrm{l})$ at site $\mathrm{C}$ in the month of April to $(1.3411 \mathrm{mg} / \mathrm{l})$ at site $\mathrm{C}$ in the month of March. The results showed that the monthly concentration of Fe was significantly different $(\mathrm{p}<0.05)$ in all the five months and their sites as well. The monthly mean value of $\mathrm{Zn}$ in the water samples ranged between $(0.4956 \mathrm{mg} / \mathrm{l})$ and $(0.0114 \mathrm{mg} / \mathrm{l})$ at sites B and A in the months of April and February Respectively. The results showed significance difference $(p<0.05)$ in months February to May in all sites respectively compared to the month of January.

\section{Heavy metal concentration in Sediment}

The monthly mean concentration of $\mathrm{Cd}, \mathrm{Cr}, \mathrm{Cu}, \mathrm{Fe}$ and $\mathrm{Zn}$ in se of sediment Lake Njoboliyo are shown in table 4, 5 and 6 . The monthly mean concentration of $\mathrm{Cd}$ in the sediment samples ranged between $0.0267 \mathrm{mg} / \mathrm{kg}$ in May and $0.0700 \mathrm{mg} / \mathrm{kg}$ in January both at sites B. There was significance difference in the months of January, February, April and May for all the different sites compared to the month of March. The highest concentration of $\mathrm{Cr}$ $(0.0467 \mathrm{mg} / \mathrm{kg})$ was recorded at site B in the month of March while the lowest concentration $(0.0144 \mathrm{mg} / \mathrm{kg}) \mathrm{was}$ recorded at site A in the month of January. There was significance difference $(p<0.05)$ from the month of JanuaryApril in all sites compared to the month of May. The monthly mean concentration of $(\mathrm{Cu})$ in the sediment ranged between $0.0166 \mathrm{mg} / \mathrm{kg}$ in the month of January at site A and $0.3533 \mathrm{mg} / \mathrm{kg}$ in May at site B. All the months and sites were not significantly different $(\mathrm{p}<0.05)$. The highest concentration of $\mathrm{Fe}(28.864 \mathrm{mg} / \mathrm{kg}) \mathrm{was}$ recorded at site $B$ in the month of February while the lowest concentration $(26.1167 \mathrm{mg} / \mathrm{kg}$ ) was recorded at site A in the month of January. There was significant differences $(p<0.05)$ in the months of January and March respectively compared to the months of February, April and May. The lowest concentration $(0.1333 \mathrm{mg} / \mathrm{kg})$ was recorded at site $\mathrm{C}$ in the month of January while the highest concentration $(0.3878 \mathrm{mg} / \mathrm{kg})$ was recorded at site B in the month of March. The results showed that the monthly mean concentration of $\mathrm{Zn}$ was significantly different $(\mathrm{p}<0.05)$ in the month of January compared to the months of February, March, April and May.

Table 1: Monthly Mean Concentration of Cadmium and Chromium (mg/L) in Water Samples

\section{Cadmium}

\begin{tabular}{|l|l|l|l|l|l|l|}
\hline Months & STATION A & STATION B & STATION C & STATION A & STATION B & STATION C \\
\hline January & $0.0144^{\mathrm{a}} \pm 0.0052$ & $0.0167^{\mathrm{a}} \pm 0.0087$ & $0.0156^{\mathrm{a}} \pm 0.0052$ & $0.0189^{\mathrm{a}} \pm 0.0078$ & $0.0222^{\mathrm{a}} \pm 0.0083$ & $0.0167^{\mathrm{a}} \pm 0.0087$ \\
\hline February & $0.0144^{\mathrm{b}} \pm 0.0052$ & $0.0222^{\mathrm{a}} \pm 0.0083$ & $0.0189^{\mathrm{a}} \pm 0.0078$ & $0.0200^{\mathrm{a}} \pm 0.0071$ & $0.0200^{\mathrm{a}} \pm 0.0087$ & $0.0200^{\mathrm{a}} \pm 0.0100$ \\
\hline March & $0.0144^{\mathrm{b}} \pm 0.0073$ & $0.0222^{\mathrm{a}} \pm 0.0067$ & $0.0167^{\mathrm{ab}} \pm 0.0071$ & $0.0189^{\mathrm{a}} \pm 0.0078$ & $0.0189^{\mathrm{a}} \pm 0.0093$ & $0.0144^{\mathrm{a}} \pm 0.0053$ \\
\hline April & $0.0222^{\mathrm{a}} \pm 0.0083$ & $0.0233^{\mathrm{a}} \pm 0.0071$ & $0.0144^{\mathrm{b}} \pm 0.0053$ & $0.0144^{\mathrm{b}} \pm 0.0053$ & $0.0211^{\mathrm{ab}} \pm 0.0093$ & $0.0222^{\mathrm{a}} \pm 0.0067$ \\
\hline May & $0.0256^{\mathrm{a}} \pm 0.0053$ & $0.0144^{\mathrm{b}} \pm 0.0053$ & $0.0222^{\mathrm{a}} \pm 0.0083$ & $0.0133^{\mathrm{b}} \pm 0.0050$ & $0.0167^{\mathrm{a}} \pm 0.0050$ & $0.0222^{\mathrm{a}} \pm 0.0097$ \\
\hline
\end{tabular}

Table 2: Monthly Mean Concentration of Copper and Iron $(\mathrm{mg} / \mathrm{L})$ in Water Samples Copper

\begin{tabular}{|l|l|l|l|l|l|l|}
\hline Months & STATION A & STATION B & STATION C & STATION A & STATION B & STATION C \\
\hline January & $0.0189^{\mathrm{a}} \pm 0.0093$ & $0.0156^{\mathrm{a}} \pm 0.0073$ & $0.0222^{\mathrm{a}} \pm 0.0083$ & $2.8800^{\mathrm{a}} \pm 0.7321$ & $1.3656^{\mathrm{b}} \pm 0.0976$ & $1.4356^{\mathrm{b}} \pm 0.1305$ \\
\hline February & $0.0189^{\mathrm{a}} \pm 0.0078$ & $0.0244^{\mathrm{a}} \pm 0.0053$ & $0.0156^{\mathrm{b}} \pm 0.0053$ & $2.1656^{\mathrm{b}} \pm 0.0938$ & $2.1656^{\mathrm{b}} \pm 0.0938$ & $2.8878^{\mathrm{a}} \pm 0.5165$ \\
\hline March & $0.0167^{\mathrm{a}} \pm 0.0071$ & $0.0189^{\mathrm{a}} \pm 0.0060$ & $0.0133^{\mathrm{a}} \pm 0.0050$ & $3.3189^{\mathrm{a}} \pm 0.1958$ & $3.3189^{\mathrm{a}} \pm 0.1958$ & $1.3411^{\mathrm{c}} \pm 0.0271$ \\
\hline April & $0.0200^{\mathrm{ab}} \pm 0.0087$ & $0.0244^{\mathrm{a}} \pm 0.0053$ & $0.0144^{\mathrm{b}} \pm 0.0053$ & $2.4200^{\mathrm{b}} \pm 0.9306$ & $2.4200^{\mathrm{b}} \pm 0.9306$ & $4.2600^{\mathrm{a}} \pm 0.2019$ \\
\hline May & $0.0144^{\mathrm{a}} \pm 0.0053$ & $0.0178^{\mathrm{a}} \pm 0.0083$ & $0.0133^{\mathrm{a}} \pm 0.0050$ & $2.1989^{\mathrm{a}} \pm 0.00169$ & $2.1989^{\mathrm{a}} \pm 0.00169$ & $1.6422^{\mathrm{b}} \pm 0.2028$ \\
\hline
\end{tabular}

Table 3:Monthly Mean Concentration of Zinc (mg/L) in Water Samples

\begin{tabular}{|l|l|l|l|}
\hline Months & STATION A & STATION B & STATION C \\
\hline January & $0.2167^{\mathrm{a}} \pm 0.1111$ & $0.3200^{\mathrm{a}} \pm 0.1642$ & $0.2900^{\mathrm{a}} \pm 0.0808$ \\
\hline February & $0.0114^{\mathrm{c}} \pm 0.0347$ & $0.2744^{\mathrm{b}} \pm 0.0541$ & $0.4822^{\mathrm{a}} \pm 0.0109$ \\
\hline March & $0.3678^{\mathrm{a}} \pm 0.0097$ & $0.0800^{\mathrm{c}} \pm 0.0100$ & $0.1567^{\mathrm{b}} \pm 0.07053$ \\
\hline April & $0.2178^{\mathrm{c}} \pm 0.0763$ & $0.4956^{\mathrm{a}} \pm 0.0142$ & $0.3222^{\mathrm{b}} \pm 0.0130$ \\
\hline May & $0.4733^{\mathrm{a}} \pm 0.0265$ & $0.2322^{\mathrm{b}} \pm 0.0222$ & $0.1622^{\mathrm{c}} \pm 0.0360$ \\
\hline
\end{tabular}


Table 4: Monthly Mean Concentration of Cadmium and Chromium (mg/kg) in Sediment Samples Cadmium

\begin{tabular}{|l|l|l|l|l|l|l|}
\hline Months & STATION A & STATION B & STATION C & STATION A & STATION B & STATION C \\
\hline January & $0.0533^{\mathrm{b}} \pm 0.0112$ & $0.0700^{\mathrm{a}} \pm 0.0087$ & $0.0611^{\mathrm{a}} \pm 0.0117$ & $0.0144^{\mathrm{b}} \pm 0.0053$ & $0.0256^{\mathrm{a}} \pm 0.0053$ & $0.0200^{\mathrm{ab}} \pm 0.0087$ \\
\hline February & $0.0444^{\mathrm{ab}} \pm 0.0113$ & $0.0567^{\mathrm{a}} \pm 0.0240$ & $0.0311^{\mathrm{b}} \pm 0.0093$ & $0.0200^{\mathrm{b}} \pm 0.0087$ & $0.0189^{\mathrm{b}} \pm 0.0093$ & $0.0300^{\mathrm{a}} \pm 0.0112$ \\
\hline March & $0.0522^{\mathrm{a}} \pm 0.0338$ & $0.0356^{\mathrm{a}} \pm 0.0101$ & $0.0311^{\mathrm{a}} \pm 0.0093$ & $0.0267^{\mathrm{b}} \pm 0.0100$ & $0.0467^{\mathrm{a}} \pm 0.0141$ & $0.0200^{\mathrm{b}} \pm 0.0087$ \\
\hline April & $0.0522^{\mathrm{a}} \pm 0.0083$ & $0.0422^{\mathrm{b}} \pm 0.0097$ & $0.0511^{\mathrm{a}} \pm 0.0078$ & $0.0178^{\mathrm{b}} \pm 0.0083$ & $0.0189^{\mathrm{b}} \pm 0.0078$ & $0.0278^{\mathrm{a}} \pm 0.0109$ \\
\hline May & $0.0289^{\mathrm{a}} \pm 0.0078$ & $0.0267 \mathrm{a} \pm 0.0050$ & $0.0311 \mathrm{a} \pm 0.0078$ & $0.0222^{\mathrm{a}} \pm 0.0067$ & $0.0267^{\mathrm{a}} \pm 0.0100$ & $0.0267^{\mathrm{a}} \pm 0.0100$ \\
\hline
\end{tabular}

Table 5: Monthly Mean Concentration of Copper and Iron $(\mathrm{mg} / \mathrm{kg})$ in Sediment Samples

Copper
\begin{tabular}{|l|l|l|l|l|l|l|}
\hline & Iron \\
\hline Months & STATION A & STATION B & STATION C & STATION A & STATION B & STATION C \\
\hline February & $0.1667^{\mathrm{a}} \pm 0.0100$ & $0.1722^{\mathrm{a}} \pm 0.0109$ & $0.1767^{\mathrm{a}} \pm 0.0100$ & $26.1167^{\mathrm{b}} \pm 1.2972$ & $28.3756^{\mathrm{a}} \pm 0.9035$ & $26.9733^{\mathrm{b}} \pm 1.8166$ \\
\hline March & $0.2344^{\mathrm{a}} \pm 0.0577$ & $0.3022^{\mathrm{a}} \pm 0.0781$ & $0.2533^{\mathrm{a}} \pm 0.0794$ & $27.5867^{\mathrm{a}} \pm 2.2131$ & $28.8644^{\mathrm{a}} \pm 1.9103$ & $27.8267^{\mathrm{a}} \pm 2.2062$ \\
\hline April & $0.3078^{\mathrm{a}} \pm 0.1058$ & $0.2467^{\mathrm{a}} \pm 0.0245$ & $0.2322^{\mathrm{a}} \pm 0.0299$ & $26.8544^{\mathrm{b}} \pm 0.7966$ & $26.8544^{\mathrm{b}} \pm 0.7966$ & $27.6767^{\mathrm{a}} \pm 0.8745$ \\
\hline May & $0.3389^{\mathrm{a}} \pm 0.0867$ & $0.3411^{\mathrm{a}} \pm 0.090$ & $0.2944^{\mathrm{a}} \pm 0.0635$ & $27.4911^{\mathrm{a}} \pm 0.8780$ & $27.4911^{\mathrm{a}} \pm 0.8780$ & $26.9289^{\mathrm{a}} \pm 1.4234$ \\
\hline
\end{tabular}

Table 6:Monthly Mean Concentration of Zinc ( $\mathrm{mg} / \mathrm{kg})$ in Sediment Samples

\begin{tabular}{|l|l|l|l|}
\hline Months & STATION A & STATION B & STATION C \\
\hline January & $0.1633^{\mathrm{b}} \pm 0.0522$ & $0.2300^{\mathrm{a}} \pm 0.0087$ & $0.1333^{\mathrm{b}} \pm 0.0100$ \\
\hline February & $0.2400^{\mathrm{a}} \pm 0.0747$ & $0.2311^{\mathrm{a}} \pm 0.0694$ & $0.2278^{\mathrm{a}} \pm 0.0707$ \\
\hline March & $0.3867^{\mathrm{a}} \pm 0.0335$ & $0.3878^{\mathrm{a}} \pm 0.1354$ & $0.3111^{\mathrm{a}} \pm 0.0595$ \\
\hline April & $0.3711^{\mathrm{a}} \pm 0.1449$ & $0.3400^{\mathrm{a}} \pm 0.1186$ & $0.3267^{\mathrm{a}} \pm 0.1519$ \\
\hline May & $0.3222^{\mathrm{a}} \pm 0.0943$ & $0.3089^{\mathrm{a}} \pm 0.0713$ & $0.3522^{\mathrm{a}} \pm 0.0781$ \\
\hline
\end{tabular}

Note: Means with the same letter are not significantly different $(>0.05)$

\section{DISCUSSION}

\section{Heavy Metals in Water}

The monthly mean concentration of Cadmium $(\mathrm{Cd})$ in the water fluctuated between $0.0144 \mathrm{mg} / 1 \mathrm{and} 0.0256 \mathrm{mg} / \mathrm{l}$. Higher concentration of cadmium is extremely toxic to fish population. The levels of cadmium in the water samples during the period of the research were above the WHO (2004) permissible limits of $0.003 \mathrm{mg} / \mathrm{l}$ for the survival of aquatic organism. The high levels of $\mathrm{Cd}$ obtained in water samples might be due to agricultural runoff, where fertilizers, pesticides and other agro-chemicals are used in addition to possible release of sediment bound metal. Cadmium contamination in the environment has caused several human sufferings. The most significant is the itai itai disease, bone deformity, severe pain of bones and joints (Francis, 1994).

The monthly mean concentration of Chromium (Cr) in the water samples ranged between $0.0133 \mathrm{mg} / 1 \mathrm{and}$ $0.0222 \mathrm{mg} / \mathrm{l}$ during the period of the study. The monthly mean concentration of chromium was higher than the recommended standard $0.003 \mathrm{mg} / \mathrm{l}$ approved by the W.H.O (2004). The high concentration of Cr in water may be due to wastes of industrial process such metal plating, or in over flow water from large air conditioning units where chromium is frequently added to cooling water to control corrosion. Chromium is considered to be a toxic chemical. Certain shellfish are capable of organism, human or animals (Gilbert and Weiss, 2006).

The monthly mean concentration of Copper $(\mathrm{Cu})$ in the water samples recorded in the period of the study in Lake Njoboliyo ranged from $0.0133 \mathrm{mg} / 1$ to $0.00244 \mathrm{mg} / \mathrm{l}$. The monthly mean concentration Cu recorded was lower than the permissible limit of $0.05 \mathrm{mg} / \mathrm{l}$ by WHO (2004). The low accumulation of copper could be due to the low industrial activity. Copper is usually found only in small amount (less than 1ppm) in natural waters. Elevated amounts may be due to industrial effluents corrosion of pipes and fittings. Copper compounds are added to fertilizer and other animal feeds as nutrient to support plants and animal growth. It is also used as food additives (Abbasi et al., 1998). Deficiency of copper may lead to anaemia, kidney and liver damage and intestinal tract problems (Gomez et al., 2000).

The monthly mean concentration of Iron (Fe) in the water samples ranged from $1.3411 \mathrm{mg} / 1$ to $4.2600 \mathrm{mg} / 1$. The values recorded were higher than the permissible limit of $0.3 \mathrm{mg} / \mathrm{l}$ standard by WHO (2004). The high concentration may be due to the dumped sites located around the Lake, these waste products are washed into the River leading to high accumulation. Iron is important in human nutrition while high concentration may cause serious water pollution, diarrhea, cardiovascular diseases (Joseph et al., 2012).

The mean concentration of Zinc ( $\mathrm{Zn})$ in the water samples ranged from $0.0114 \mathrm{mg} / 1$ to $0.4956 \mathrm{mg} / \mathrm{l}$. The values found to be higher than the standard $0.3 \mathrm{mg} / 1$ by WHO (2004). Zinc plays a significance role in the biochemical processes of all aquatics. It is important in the growth of plants and animals, however, elevated levels may be toxic to some aquatic species (WHO, 2004). The high concentration may be due to excessive concentration in soils since it is employed as a weed killer (Abbasi et al., 1998). Zinc carbonates are used as pesticides and are used in steel 
galvanizing products (Anglin-Brown et al., 1995).

\section{Heavy Metals in Sediments}

Sediments are metal reservoirs trapping all the heavy metals that escape detection in water. Research has it that nearly all metals content in aquatic environment resides in water sediment (Ademorati, 1996). The highest Cadmium in sediment samples was $0.0700 \mathrm{mg} / \mathrm{kg}$ in the month of January. This could be due to the dry season which usually makes metals to be in high concentration. The high value might be due to municipal wastes comprising several cadmium sources like iron and steel scrap, plastics, cement etc. The lowest value of cadmium $0.0267 \mathrm{mg} / \mathrm{kg}$ in the month of May. This could be due to high water volume which might have triggered the low level of Cadmium. The Values of Cadmium recorded in this study exceeded the allowable limit of $0.003 \mathrm{mg} / \mathrm{kg}$ to $0.3 \mathrm{mg} / \mathrm{kg}$ as recommended by FEPA (1991) and WHO (2003).

The highest Chromium in sediment samples was $0.0467 \mathrm{mg} / \mathrm{kg}$ in the month of March while the lowest value $(0.0144 \mathrm{mg} / \mathrm{kg})$ was recorded in the month January. According to Adefemi et al. (2007) chromium in water originates from natural sources such as weathering, wet precipitation and dry fallout from the atmosphere and washed out from the terrestrial systems. The local increase in chromium concentration in water (mainly in rivers) is caused by discharge of wastewater from metallurgical industry, electroplating and tanning industries, from dying and other chemical industries. Chromium did not exceed the allowable limit of $0.10 \mathrm{mg} / \mathrm{kg}$ recommended by FEPA, (1991).

The values of Copper ranged between $0.1667 \mathrm{mg} / \mathrm{kg}$ in the month of January and $0.3533 \mathrm{mg} / \mathrm{kg}$ in the month of May. The reason for high values of copper in the site could be due to municipal waste being discharged in the water, domestic waste, run-off from phosphate fertilizers, pesticides used on or near farms and wood preservatives in the construction of boats and canoes. Copper in sediment in this study showed that it did not exceed the allowable limit of $20 \mathrm{mg} / \mathrm{kg}$ recommended by WHO (2003).

The highest Iron concentration $28.8644 \mathrm{mg} / \mathrm{kg}$ in February while the lowest concentration $26.1167 \mathrm{mg} / \mathrm{kg}$ in January. The reason for the high value of iron in the site could be due dumped of waste products which are washed into the river either by flood or run-offs. These wastes could be from industries or factories located near the river or from agricultural activities, since farming is the main occupation in that area (Barron , 1990). The values of Iron metal in sediment recorded did not exceed the permissible limit of 30mg/kg recommended by WHO (2003) and FEPA (1991).

The highest concentration of Zinc was observed at site B in the March while the lowest at site C in January. The reason for the high value of zinc in the site $\mathrm{B}$ could be due to the discharge of waste and the use of commercial products such as fertilizers and wood preservatives or the reduced volume of water and reduced anthropogenic activities. Zinc does not volatilize from water but is deposited primarily in sediment through adsorption and precipitation (ATSDR, 1999). The Zinc observed was within the permissible level of 50-300 $\mathrm{mg} / \mathrm{kg}$ recommended by WHO (2003).

\section{CONCLUSION}

In conclusion, all the heavy metals $(\mathrm{Cd}, \mathrm{Cr}, \mathrm{Fe}$ and $\mathrm{Zn})$ present in water exceeded the permissible level except $\mathrm{Cu}$, indicating that the pollution of Lake Njoboliyo is evident. All heavy metal under investigation were present in the Sediment. $\mathrm{Cr}, \mathrm{Fe}, \mathrm{Cu}$ and $\mathrm{Zn}$ All the metals were within the recommended range for unpolluted Sediments except Cd.

\section{REFERENCES}

Abbasi, S. A., Abbasi, N. and Soni, R. (1998). Heavy metals in the environment. Mittal Publication, Delhi, 314. Adebayo A.A. and Tukur, A.L. (1999). Adamawa in Maps. First edition Paraclete publishers, Yola-Nigeria.

Adefemi,S.S, Asoulu,S.S and Olaofe, O. (2007). Assessment of physicochemical status of Water of Maji Dams in Ekiti State. Nigerian Partisan Journal of Nutrition, 6(6) 657-659.

Ademoroti, C.M.A. (1996): Environmental Chemistry and Toxicology, Foludex Press Ltd., Ibadan pp. 171 - 204. Ademoroti, C.M.A. (1996a). Standard Methods for Water and Effluent Analysis. Ibadan; Foludex Press Ltd, pp. 182

Ajayi, M. S. O and Osibbanjo, O. (1981).Pollution Studies on Nigerian Rivers: Toxic Heavy metals Status of Surface Water in Ibadan City, 49-53.

Anglin, B., Armour, B. A. and Lalor, G. C. (1995). Heavy metals pollution in jamaica1: Survey of Cadmium, Lead and Zinc Concentrations in the Kintyre and hope flat districts, Environment Geochemistry and Health, 17, $51-56$

APHA (199 5). Standard Methods for the Examination of Water and Waste Water. (15th Edition) Washington, D.C.

APHA. (2005). Standard Methods for the Examination of Water and Waste-Water. $21^{\text {st }}$ Edn. Washington, D.C. ATSDR, (Agency for Toxic Substances and Disease Registry) (1999). Toxicological Profile for zinc. U S Dept of 
Health and Human Service. Atlanta 204- 552-606

Barron, G. M. (1990). Bio-concentration of heavy metals. Journal of Environmental Science-china 20, 413-418

Bartly, G. E and Gardner, D. (1977). Sampling and storage of Natural waters for trace metal Analysis. Water res. 2:745-756.

Collocott, T.C, and Dabson, A. (1974). Chambers Science and Technology Dictionary. Chambers Edinburgh.Pp.56.

Federal Environmental Projection Agency (FEPA). (2003). Guidelines and Standards for environmental pollution control in Nigeria. Nigeria.

FEPA, (1991): Guideline and Standards for Environmental Pollution and $\quad$ Control in Nigeria. Federal Environmental Protection Agency, Nigeria.

Food and Agriculture Organization (FAO). 1992. Report of the third Session of Working Party on Pollution and Fisheries, Accra, Ghana,25-29 ${ }^{\text {th }}$ Nov., 1991. FAO Fisheries Report. 471: 43.

Francis,U. (1994). Metal pollution in Aquatic environment Siring Berlin, Newwork, USA.

Gomez, A. J. L., Giraldez, I., Sanchez-rodas, D. and Morales, E. (2000). Comparison of the feasibility of three extration procedures for trace metal partitioning in sediments from South West Spain. Science of the Total Environment, 246(2-3), 271-283

Jackson, R.B., Carpenter, S.R., Dahm, C.N., Mcknight, D.M., Naiman, R.J., Postel, S.L and Running SW (2001). Water in changing World. Issues in Ecology, No 9:2-16 Ecological Society of America, Washington DC.

Joseph, C. A., Mohammed, T. A., Zaynab, M. C. and Fanna, I. A. (2012). Assessment of pollutants in water and sediment samples in Lake Chad, Baga, North Eastern Nigeria. Journal of Environmental Protection 3, 14281441

Ladigbolu,I. A (2010). Distribution of Heavy Metals in the sediments of

selected Streams in Ibadan Metropolis, Nigeria. International Journal of Chemistry, Vol.2 No 1.

Ladu,B.M.B and Neiland,A (1997). A review of Fisheries Policy in Nigeria since 1950 (with special Reference to Inland Fisheries of North Eastern Nigeria); Center for Economics and Management of Aquatic Resources Paper 126.1997:34

Lee, S.V. and A.B. Cundy.( 2001). Heavy metal contamination and mixing process in Sediments from the Humber estuary, Eastern England. Est. Coast. Shelf Sci.53: 619-636.

Philips, M.J. (1990). Analysis of Nutrients.In Stirlings, H.P (Ed). Chemical and Biological Methods of Water Analysis for Aquaculturiest. $1^{\text {st }}$ Edition Institute of Aquaculture.University of Stirling. Printed and made in Great Britain. 110

Santra,S, Zhao,X and Tan, W (2005). Analytical Chemistry 78 (3), 646-654.

Steel, R.D.D and Torrie, J. H. (1990).Principle and Procedure of Statistics. A Biometric Approach $2^{\text {nd }}$ Edition.McGraw Hill, Newyork Pp. 633.

Wetzel, R. G. (1979). Limnology.Lakes and River Ecosystem.Academic Press.Third Edition.Pp. 743.

World Health Organization (1992): Environmental health criteria.No.134. Cadmium. WHO. Geneva. www.freepatentsonline.com/5958248.htm.

World Health Organization (WHO) (2004). World Health Organization (WHO) standards for Drinking Water. Guidelines for Drinking Water Quality Recommendations. France, 181.

World Health Organization (WHO). (2003). Heavy Metal regulation: Legal no notices no 66www.Discoverlife.2008 